\title{
PERSPEKTIF MAKNA KOMUNIKASI ISLAM
}

\author{
Haslinda \\ Mahasiswa Doktoral Program Pasca Sarjana \\ Universitas Islam Negeri Sumatera Utara
}

\begin{abstract}
Abstrak
Salah satu hal yang sangat berpengaruh dalam perkembangan islam pada saat itu adalah kemampuan komunikasi Rosulullah dan para sahabat yang tidak diragukan lagi, dimana Rasulullah dan para sahabat menerapkan seluruh prinsip-prinsip komunikasi yang ada didalam al-Qur'an dengan konsisten, sehingga manusia yang secara kodrati adalah makhluk sosial yang pasti akan saling berinteraksi antara satu dan lain serta saling membutuhkan sangatlah tertarik dengan sistem komunikasi yang digunakan karana mudah diterima serta dipahami.Komunikasi selain bersifat informatif, yakni agar orang lain mengerti dan paham, juga persuasif, yaitu agar orang lain mau menerima ajaran atau informasi yang disampaikan, melakukan kegiatan atau perbuatan sesuai dengan yang dikomunikasikan, dan lain-lain.Al-Qur'an telah mengajarkan kita tentang bagaimana cara berkomunikasi dengan baik, walaupun tidak menjelaskannya secara rinci, namun kita dapat menemukannya dalam beberapa ayat yang membaahas tentang itu dan akan kami bahas dalam makalah ini dan hal itu juga telah dicontohkan oleh Rosulullah dan sahabatsahabatnya, sehingga kita dapt mengikuti jejaknya dan tentunya agar dakwah yasng kita lakukan sesuai dengan yang kita harapkan.
\end{abstract}

Kata Kunci : Perspektif Makna, Komunikasi Islam 


\section{A. PENDAHULUAN}

Islam adalah salah satu agama terbesar yang ada di dunia ini. Dengan jumlah pemuluk lebih dari satu miliar jiwa yang tersebar diseluruh dunia. Namun ada satu hal menarik yang harus kita perhatikan, yaitu tentang kesuksesan Rasulullah dalam menebarkan islam. Dimana hanya dalam jangka dua puluh tiga tahun Rasulullah telah mampu menyebarkan islam keseluruh jazirah arabia bahkan sampai ke negara tetangga yang kemudian dakwahnya dilanjutkan oleh para sahabat sehingga daerah kekuasaan islam semakin luas. Yang menjadi permasalahan disini adalah bagaimana cara Rosulullah dan para sahabat dalam menyebarkan dakwahnya sehingga islam mampu berkembang dalam waktu yang cukup cepat.

Salah satu hal yang sangat berpengaruh dalam perkembangan islam pada saat itu adalah kemampuan komunikasi Rosulullah dan para sahabat yang tidak diragukan lagi, dimana Rasulullah dan para sahabat menerapkan seluruh prinsip-prinsip komunikasi yang ada didalam al-Qur'an dengan konsisten, sehingga manusia yang secara kodrati adalah makhluk sosial yang pasti akan saling berinteraksi antara satu dan lain serta saling membutuhkan sangatlah tertarik dengan sistem komunikasi yang digunakan karana mudah diterima serta dipahami.

Komunikasi selain bersifat informatif, yakni agar orang lain mengerti dan paham, juga persuasif, yaitu agar orang lain mau menerima ajaran atau informasi yang disampaikan, melakukan kegiatan atau perbuatan sesuai dengan yang dikomunikasikan, dan lain-lain.

Al-Qur'an telah mengajarkan kita tentang bagaimana cara berkomunikasi dengan baik, walaupun tidak menjelaskannya secara rinci, namun kita dapat menemukannya dalam beberapa ayat yang membaahas tentang itu dan akan kami bahas dalam makalah ini dan hal itu juga telah dicontohkan oleh Rosulullah dan sahabat-sahabatnya, sehingga kita dapt mengikuti jejaknya dan tentunya agar dakwah yasng kita lakukan sesuai dengan yang kita harapkan.

\section{B. KOMUNIKASI}

Sesuai pengertian dan model komunikasi, komunikasi dapat dilihat dari berbagai dimensi yakni sebagai berikut : 


\section{Komunikasi Sebagai Proses}

Komunikasi dipandang sebagai proses yang dimaksudkan disini ialah suatu kegiatan yang berlagsung secara dinamis. Proses yang berarti unsur - unsur yang ada di dalamnya bergerak aktif, dinamis, dan tidak statis.

\section{Komunikasi Sebagai Simbolik}

Dalam semua konteks komunikasi dimana segala sesuatunya memerlukan dan menggunakan simbol. Simbol dapat di nyatakan dalam bentuk verbal maupun non verbal, dalam setiap daerah, lingkungan atau kumpulan tertentu simbol dapat berbeda - beda sesuai dengan tempat dimana digunakanya simbol tersebut. Karena setiap daerah memaknai simbol tersebut secara berbeda - beda. Meskipun hidup dalam satu bahasa yang sama (inggris), tetapi kita banyak yang berbeda dalam kerangka budaya (MacNamara 1966).

\section{Komunikasi Sebagai Sistem}

Sistem didefinisikan sebagai suatu aktivitas dimana semua komponen atau unsur yang mendukung saling berinteraksi satu sama lain dalam menghasilkan saluran (Semprivivo 1982). Dengan kata lain sistem adalah seperangkat komponen - komponen serta unsur unsur yang terhubung dan saling bergantung satu sama lainya serta tidak dapat terpisahkan. Jika salah satu komponen tidak dapat berfungsi secara baik maka sistem itu secara otomatis tidak dapat berjalan secara normal sebagaimana mestinya, ini berarti semua komponen selain harus berinteraksi juga harus dapat berfungsi secara optimal sebagaimana mestinya. Jika dikaitkan dengan proses komunikasi dapat dikatakan bahwa komunikasi adalah suatu sistem yang dimana tercermin dari unsur - unsur yang mendukungnya sebagai suatu kesatuan antara komunikator, pesan, media, komunikan, dan timbal baliknya (feedback). Jadi, sebuah proses komunikasi tidak akan berlangsung dengan baik jika salah satu unsur didalamnya tidak dapat berfungsing dengan baik pula. Bayangkan jika komunikator, pesan dan komunikan berfungsi secara baik tetapi dalam prosesnya pesan yang disampaikan melalu media (chennel) yang tidak efektif maka tidak akan tersampaikannya pesan secara baik.

\section{Komunikasi Sebagai Aksi}

Komunikasi selalu menggunakan simbol dalam berbagai macam konteksnya, selain itu tidak dapat dipungkiri dalam berbagai komunikasi tidak pernah terjadi tanpa aksi, apakah itu diucapkan, ditulis, maupun dilakukan dalam bentuk isyarat (non verbal), bahkan gerakan dalam bentuk diam pun merupakan aksi.

5. Komunikasi Sebagai Aktifitas Sosial 
Komunikasi menjadi jembatan dalam menghubungkan antara kepentingan diri manusia sebagai individu dengan masyarakat disekelilingnya. Karena sudah menjadi sifat yang mendasar pada manusia yakni selalu berusaha untuk berhubungan dengan sesamanya, upaya ini dilakukan untuk menghilangkan keterasingan mereka dan juga untuk mengetahui apa yang sedang terjadi diluar dirinya. Apakah itu dilakukan untuk memenuhi kebutuhan hidupnya, ataukan untuk kepentingan aktualisasi diri dalam membicarakan masalah masalah politik, ekonomi, sosial, budaya, seni dan teknologi.

6. Komunikasi Sebagai Multidimensional

Terdapat dua tingkatan yang dapat diidentifikasikan dalam perspektif multidimensional ini yakni dimensi isi dan dimensi hubungan.Kedua dimensi tersebut tidak dapat saling terpisahkan dimana dimensi isi menunjukkan pada kata, bahasa, pesan serta informasi yang terkandung didalamnya. Sementara itu dimensi hubungan merujuk pada bagaimana cara komunikator dalam menyampaikan pesanya kepada komunikan atau bagaimana peserta komunikasi berinteraksi.

\section{PERSPEKTIF ILMU KOMUNIKASI}

1. Perspektif mekanistis

Perspektif mekanistis menekankan pada unsur saluran fisik komunikasi, penyampaian, dan penerimaan arus pesan diantara sumber atau para penerimannya.

2. Perspektif psikologis

Perspektif psikologis tentang komunikasi manusia memfokuskan perhatiannya pada individu (komunikator atau penafsir) baik secara teoritis maupun empiris.

3. Perspektif interaksional

Perspektif interaksional menunjukkan pandangan komunikasi manusia yang telah berkembang secara tidak langsung dari cabang sosiologi yang dikenal sebagai interaksi simbolis.

4. Perspektif pragmatis

Perspektif ini didasarkan pada asumsi pokok system dan informasi. Perspektif ini merupakan aplikasi yang sesuai dari system pada komunikasi manusia dan jelas merupakan perkembangan baru yang berbeda untuk penelitian komunikasi manusia.

5. Perspektif lain

Diantara keempat perspektif diatas, terdapat beberapa perspektif lainnya yang dianggap kecil dan kurang menyebar, yaitu: 
a) Perspektif ekologis

Komunikasi sebagai proses adaptasi organism kepada lingkungan.

b) Perspektif dramatisme

Menempatkan individu dan perilaku social dalam analogi dramatis yang menandai actor social pada "panggung" kehidupan yang sebenarnya.

c) Aliran mcluhan atau mcluhanisme

Media massa elektronik dikategorikan sebagai perangsang citra dan pencipta citra yang subliminal.

d) Teori atau model keseimbangan

Konsep tentang adanya perangkat kekuatan yang saling bertentangan yang menciptakan keresahan secara psikologis apabila mereka dalam suatu keadaan tidak seimbang. Untuk itu harus dikembalikan pada keadaan yang seimbang dengan prinsip maksimalisasi atau ekuilibrium (memberikan penekanan pada kebutuhan untuk menyamakan kekuatan yang saling bertentangan).

\section{Komunikasi Sebagai alat untuk berinteraksi}

Manusia sebagai makhluk sosial menduduki posisi yang sangat penting dan strategis. Sebab, hanya manusialah satu-satunya makhluk yang diberi karunia bisa berbicara. Dengan kemampuan bicara itulah, memungkinkan manusia membangun hubungan sosialnya. Sebagaimana bisa dipahami dari firman Allah yang artinya: "mengajarnya pandai berbicara" (al-Rahmân/55: 4). Banyak penafsiran yang muncul berkenaan dengan kata al-bayan, namun yang paling kuat adalah berbicara (al-nuthq, al-kalam). Komunikasi selain bersifat informatif, yakni agar orang lain mengerti dan paham, juga persuasif, yaitu agar orang lain mau menerima ajaran atau informasi yang disampaikan, melakukan kegiatan atau perbuatan sesuai dengan yang dikomunikasikan, dan lain-lain. Hanya saja, menurut Ibn 'Asyur, kata albayan juga mencakup isyarah-isyarah lainnya, seperti kerlingan mata, anggukan kepala dan lain-lain. Dengan demikian, al-bayan merupakan karunia yang terbesar bagi manusia. Bukan saja ia dapat dikenali jati dirinya, akan tetapi, ia menjadi pembeda dari binatang.

Kemampuan bicara berarti kemampuan berkomunikasi. Berkomunikasi adalah sesuatu yang dihajatkan di hampir setiap kegiatan manusia. Dalam sebuah penelitian telah dibuktikan, hampir $75 \%$ sejak bangun dari tidur manusia berada dalam kegiatan komunikasi. Dengan komunikasi kita dapat membentuk saling pengertian dan menumbuhkan persahabatan, memelihara kasih sayang, menyebarkan pengetahuan, dan melestarikan 
peradaban. Tetapi, dengan komunikasi kita juga dapat menumbuhsuburkan perpecahan, menghidupkan permusuhan, menanamkan kebencian, merintangi kemajuan, dan menghambat pemikiran.

Kenyataan ini sekaligus memberi gambaran betapa kegiatan komunikasi bukanlah sesuatu yang mudah dilakukan oleh setiap manusia. Anggapan ini barangkali didasarkan atas dasar asumsi bahwa komunikasi merupakan suatu yang lumrah dan alamiah yang tidak perlu dipermasalahkan. Sedemikian lumrahnya, sehingga seseorang cenderung tidak melihat kompleksitasnya atau tidak menyadari bahwa dirinya sebenarnya berkekurangan atau tidak berkompeten dalam kegiatan pribadi yang paling pokok ini. Dengan demikian, berkomunikasi secara efektif sebenarnya merupakan suatu perbuatan yang paling sukar dan kompleks yang pernah dilakukan seseorang.Untuk itu, demi terciptanya suasana kehidupan yang harmonis antar anggota masyarakat, maka harus dikembangkan bentuk-bentuk komunikasi yang beradab, yang digambarkan oleh Jalaluddin Rahmat, yaitu sebuah bentuk komunikasi di mana sang komunikator akan menghargai apa yang mereka hargai; ia berempati dan berusaha memahami realitas dari perspektif mereka. Pengetahuannya tentang khalayak bukanlah untuk menipu, tetapi untuk memahami mereka, dan bernegosiasi dengan mereka, serta bersama-sama saling memuliakan kemanusiaannya. Adapun gambaran kebalikannya yaitu apabila sang komunikator menjadikan pihak lain sebagai obyek; ia hanya menuntut agar orang lain bisa memahami pendapatnya; sementara itu, ia sendiri tidak bisa menghormati pendapat orang lain. Dalam komunikasi bentuk kedua ini, bukan saja ia telah mendehumanisasikan mereka, tetapi juga dirinya sendiri.

\section{E. Prinsip-prinsip Komunikasi dalam al-Qur'an}

Al-qur'an tidak membahas secara rinci tntang prinsip-prinsip komunikasi, namun dalam al-Qur'an Allah telah memberikan berbagai pengibaratan yang secara tidak lansung menyarankan kita agar bisa berkomunikasi dengan baik,apalagi Rasulullah pun telah mencontokannya pada kita. Kata 'komunikasi' berasal dari bahasa Latin, communicatio, dan bersumber dari kata cummunis yang berarti sama, maksudnya sama makna. Artinya, suatu komunikasi dikatakan komunikatif jika antara masing-masing pihak mengerti bahasa yang digunakan, dan paham terhadap apa yang dipercakapkan.Dalam proses komunikasi, paling tidak, terdapat tiga unsur, yaitu komunikator, media dan komunikan. 
Para pakar komunikasi menjelaskan bahwa komunikasi tidak hanya bersifat informatif (agar orang lain mengerti dan paham), tapi juga persuasif (agar orang lain mau menerima ajaran atau informasi yang disampaikan, melakukan kegiatan atau perbuatan, dan lain-lain). Menurut Hovland, seperti yang dikutip oleh Onong U, bahwa berkomunikasi bukan hanya terkait dengan penyampaian informasi, tapi juga bertujuan pembentukan pendapat umum (public opinion) dan sikap publik (public attitude).

Kedua, meskipun al-Qur'an secara spesifik tidak membicarakan masalah komunikasi, namun, jika diteliti ada banyak ayat yang memberikan gambaran umum prinsip-prinsip komunikasi. Dalam hal ini, kami merujuk pada term-term khusus yang diasumsikan sebagai penjelasan dari prinsip-prinsip komunikasi tersebut. Antara lain, term qaulan baligha, qaulan maisura, qaulan karima, qaulan ma'rufa, qaulan layyina, qaulan sadida, dan lain-lain.

\section{Prinsip Qaulan Baligha (قَّْ لَا بَلِيغًام)}

Di dalam al-Qur'an kata qaul baligha, yaitu surah an-Nisa': 63, yaitu berbicara dengan menggunakan ungkapan yang mengena, mencapai sasaran dan tujuan, bicaranya jelas, terang, dan tepat. Ini berarti bahwa bicaranya efektif.

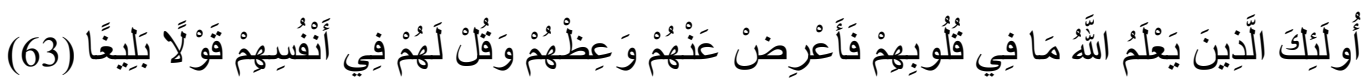

"Mereka itu adalah orang-orang yang (sesungguhnya) Allah mengetahui apa yang ada di dalam hatinya. Karena itu berpalinglah kamu dari mereka, dan berilah mereka nasihat, dan katakanlah kepada mereka perkataan yang membekas pada jiwanya." (Q.s. an-Nisa'/4: 63)

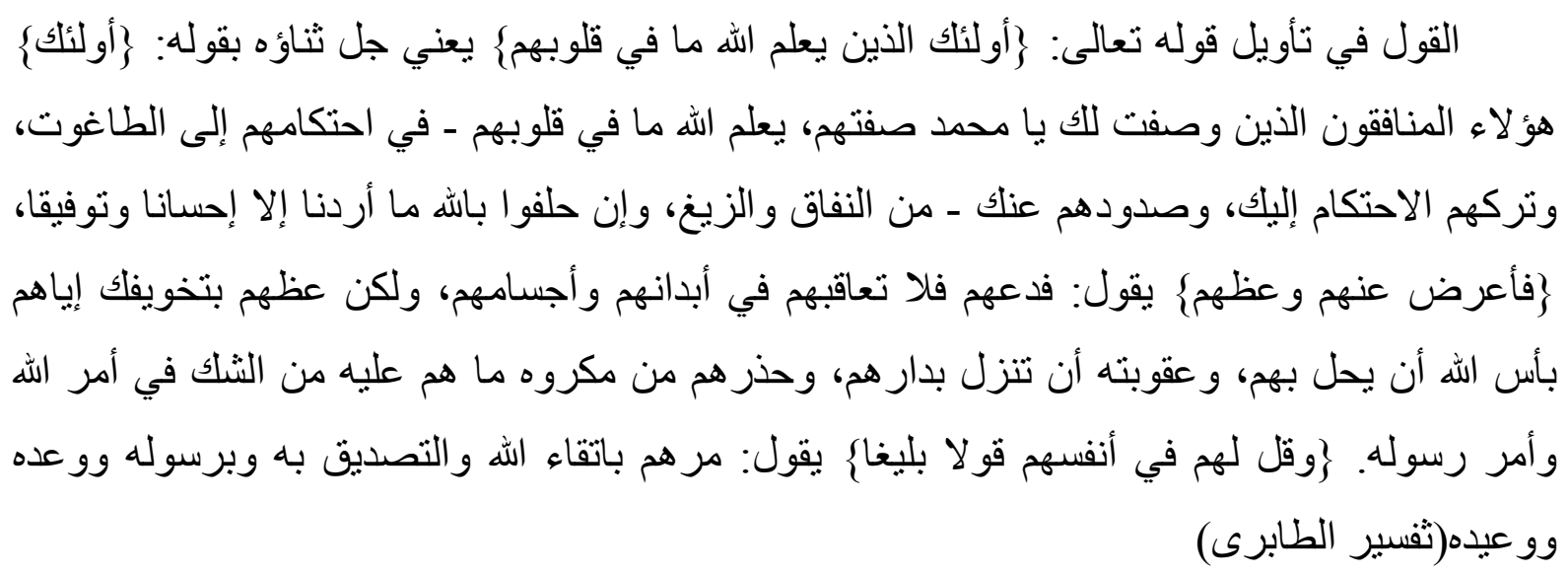

Ayat ini menginformasikan tentang kebusukan hati kaum munafik, bahwa mereka tidak akan pernah bertahkim kepada Rasulullah saw, meski mereka bersumpah atas nama Allah, kalau apa yang mereka lakukan semata-mata hanya menghendaki kebaikan. Walapun begitu, beliau dilarang menghukum mereka secara fisik (makna dari "berpalinglah dari 
mereka"), akan tetapi, cukup memberi nasehat sekaligus ancaman bahwa perbuatan buruknya akan mengakibatkan turunnya siksa Allah, dan berkata kepada mereka dengan perkataan yang baligh.

Kata baligh, yang berasal dari balagha, oleh para ahli bahasa dipahami sampainya sesuatu kepada sesuatu yang lain. Juga bisa dimaknai dengan "cukup" (al-kifayah). Perkataan yang baligh adalah perkataan yang merasuk dan membekas di jiwa. Sementara menurut alIshfahani, bahwa perkataan tersebut mengandung tiga unsur utama, yaitu bahasanya tepat, sesuai dengan yang dikehendaki,dan isi perkataan adalah suatu kebenaran. Sedangkan term baligh dalam konteks pembicara dan lawan bicara, adalah bahwa si pembicara secara sengaja hendak menyampaikan sesuatu dengan cara yang benar agar bisa diterima oleh pihak yang diajak bicara.

Secara rinci, para pakar sastra, seperti yang dikutip oleh Quraish Shihab, membuat kriteria-kriteria khusus tentang suatu pesan dianggap baligh, antara lain:

a. Tertampungnya seluruh pesan dalam kalimat yang disampaikan

b. Kalimatnya tidak bertele-tele, juga tidak terlalu pendek sehingga pengertiannya menjadi kabur

c. Pilihan kosa katanya tidak dirasakan asing bagi si pendengar

d. Kesesuaian kandungan dan gaya bahasa dengan lawan bicara

e. Kesesuaian dengan tata bahasa.

\section{Prinsip Qaulan Karima(قَّوْلَا كَرِيمًا)}

Kata ini ditemukan di dalam al-Qur'an hanya sekali, yaitu surah al-Isra': 23 yaitu berbicara mulia yang menyiratkan kata yang isi, pesan, cara serta tujuannya selalu baik, terpuji penuh hormat, mencerminkan akhlak terpuji dan mulia.

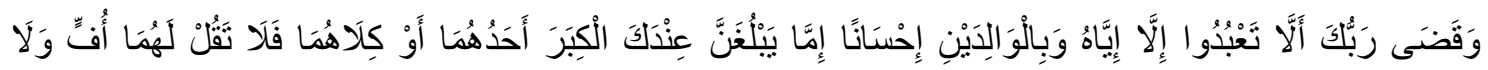

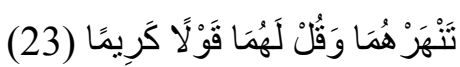

"Dan Tuhanmu telah memerintahkan agar kamu jangan menyembah selain Dia dan hendaklah berbuat baik kepada ibu bapak. Jika salah seorang di antara keduanya atau kedua-duanya sampai berusia lanjut dalam pemeliharaanmu, maka sekali-kali janganlah engkau mengatakan kepada keduanya perkataan "ah" dan janganlah engkau membentak keduanya, dan ucapkanlah kepada keduanya perkataan yang baik." (Q.s. al-Isra'/17: 23)

Ayat ini menginformasikan bahwa ada dua ketetapan Allah yang menjadi kewajiban setiap manusia, yaitu menyembah Allah dan berbakti kepada kedua orang tua. Ajaran ini 
sebenarnya ajaran kemanusiaan bersifat umum, karena setiap manusia pasti menyandang dua predikat ini sekaligus, yakni sebagai makhluk ciptaan Allah, yang oleh karenanya harus menghamba kepada-Nya semata; dan anak dari kedua orang tuanya. Sebab, kedua orang tuanyalah yang menjadi perantara kehadirannya di muka bumi ini. Bukan hanya itu, struktur ayat ini, di mana dua pernyataan tersebut dirangkai dengan huruf wawu 'athaf, yang salah satu fungsinya adalah menggabungkan dua pernyataan yang tidak bisa saling dipisahkan, menunjukkan bahwa berbakti kepada kedua orag tua menjadi parameter bagi kualitas penghambaan manusia kepada Allah.

Dalam sebuah hadis riwayat Ahmad, Nabi Saw. Bersabda:

"Merugilah $3 x$, seseorang yang menemukan salah satu atau kedua orang tuanya sudah lanjut usia tidak bisa masuk surga."

Berkaitan dengan inilah, al-Qur'an memberikan petunjuk bagaimana cara berprilaku dan berkomunikasi secara baik dan benar kepada kedua orang tua, terutama sekali, di saat keduanya atau salah satunya sudah berusia lanjut. Dalam hal ini, al-Qur'an menggunakan term karim, secara kebahasaan berarti mulia. Ini bisa disandarkan kepada Allah, misalnya, Allah Maha Karim, artinya Allah Maha Pemurah; juga bisa disandarkan kepada manusia, yaitu menyangkut keluhuran akhlak dan kebaikan prilakunya. Artinya, seseorang dikatakan karim, jika kedua hal itu benar-benar terbukti dan terlihat dalam kesehariannya.

Namun, jika term karima dirangkai dengan kata qaul atau perkataan, maka berarti suatu perkataan yang menjadikan pihak lain tetap dalam kemuliaan, atau perkataan yang membawa manfaat bagi pihak lain tanpa bermaksud merendahkan. Disinilah Sayyid Quthb menyatakan bahwa perkataan yang karim, dalam konteks hubungan dengan kedua orang tua, pada hakikatnya adalah tingkatan tertinggi yang harus dilakukan oleh seorang anak. Yakni, bagaimana ia berkata kepadanya, namun keduanya tetap merasa dimuliakan dan dihormati. Ibn 'Asyur menyatakan bahwa qaul karim adalah perkataan yang tidak memojokkan pihak lain yang membuat dirinya merasa seakan terhina. Contoh yang paling jelas adalah ketika seorang anak ingin menasehati orang tuanya yang salah, yakni dengan tetap menjaga sopan santun dan tidak bermaksud menggurui, apalagi sampai menyinggung perasaannya. Yang pasti qaul karima, adalah setiap perkataan yang dikenal lembut, baik, yang mengandung unsur pemuliaan dan penghormatan. 


\section{Prinsip Qaulan Maysura (قَوًَْ مَيْسُورًا)}

Di dalam al-Qur'an hanya ditemukan sekali saja, yaitu surah al-Isra'/17: 28, yaitu berbicara dengan baik dan pantas, agar orang tidak kecewa.

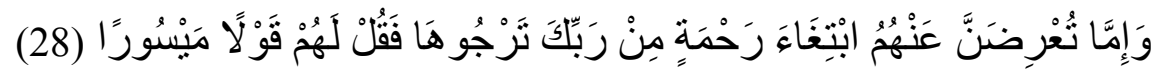

"Dan jika engkau berpaling dari mereka untuk memperoleh rahmat dari Tuhanmu yang engkau harapkan, maka katakanlah kepada mereka ucapan yang lemah lembut." (Q.s. al-Isra'/17: 28)

Ibn Zaid berkata, "Ayat ini turun berkenaan dengan kasus suatu kaum yang minta sesuatu kepada Rasulullah saw namun beliau tidak mengabulkan permintaannya, sebab beliau tahu kalau mereka seringkali membelanjakan harta kepada hal-hal yang tidak bermanfaat. Sehingga berpalingnya beliau adalah semata-mata karena berharap pahala. Sebab, dengan begitu beliau tidak mendukung kebiasaan buruknya dalam menghambur-hamburkan harta. Namun begitu, harus tetap berkata dengan perkataan yang menyenangkan atau melegakan."

Ayat ini juga mengajarkan, apabila kita tidak bisa memberi atau mengabulkan permintaan karena memang tidak ada, maka harus disertai dengan perkataan yang baik dan alasan-alasan yang rasional. Pada prinsipnya, qaul maisur adalah segala bentuk perkataan yang baik, lembut, dan melegakan. Ada juga yang menjelaskan, qaul maisura adalah menjawab dengan cara yang sangat baik, perkataan yang lembut dan tidak mengada-ada. Ada juga yang mengidentikkan qaul maisura dengan qaul ma'ruf. Artinya, perkataan yang maisur adalah ucapan yang wajar dan sudah dikenal sebagai perkataan yang baik bagi masyarakat setempat.

\section{Prinsip Qaulan Ma'rufa(قًََْْا مَعْرُوفًاف)}

Di dalam al-Qur'an kata ini disebutkan sebanyak empat kali, yaitu Q.s. al-Baqarah/2: 235, al-Nisa'/4: 5 dan 8, al-Ahzab/33: 32. Al-Qur'an surah An-Nisa'/4: 8 berbunyi:

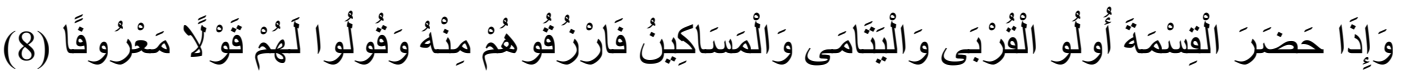

"Dan apabila sewaktu pembagian itu hadir kerabat, anak yatim dan orang miskin, maka berilah mereka dari harta itu (sekedarnya) dan ucapkanlah kepada mereka perkataan yang baik." (an-Nisa'/4: 8)

Di dalam Q.s. al-Baqarah/2: 235, qaul ma'rufa disebutkan dalam konteks meminang wanita yang telah ditinggal mati suaminya. Sementara di dalam Q.s. an-Nisa'/4: 5 dan 8, qaul ma'ruf dinyatakan dalam konteks tanggung jawab atas harta seorang anak yang belum me- 
manfaatkannya secara benar (safih). Sedangkan di Q.s. al-Ahzab/33: 32, qaul ma'ruf disebutkan dalam konteks istri-istri Nabi Saw.

Dalam beberapa konteks al-Razi menjelaskan, bahwa qaul ma'ruf adalah perkataan yang baik, yang menancap ke dalam jiwa, sehingga yang diajak bicara tidak merasa dianggap bodoh (safih); perkataan yang mengandung penyesalan ketika tidak bisa memberi atau membantu; Perkataan yang tidak menyakitkan dan yang sudah dikenal sebagai perkataan yang baik.

\section{Prinsip Qaulan Layyina (قَََْل}

Di dalam al-Qur'an hanya ditemukan sekali saja, Q.s. Thaha/ 20: 44 yaitu berbicara dengan lemah lembut.

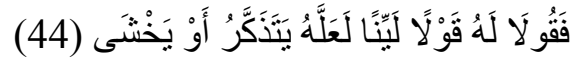

"Pergilah kamu bedua kepada Fir'aun, sesungguhnya dia benar-benar telah melampaui batas; maka berbicaralah kamu berdua kepadanya (Fir'aun) dengan kata-kata yang lemah lembut, mudah-mudahan dia sadar atau takut." (Q.s. Thaha/20: 44)

Ayat ini memaparkan kisah nabi Musa dan Harun ketika diperintahkan untuk menghadapi Fir'aun, yaitu agar keduanya berkata kepada Fir'aun dengan perkataan yang layyin. Asal makna layyina adalah lembut atau gemulai, yang pada mulanya digunakan untuk menunjuk gerakan tubuh. Kemudian kata ini dipinjam (isti'arah) untuk menunjukkan perkataan yang lembut. Sementara yang dimaksud dengan qaul layyina adalah perkataan yang mengandung anjuran, ajakan, pemberian contoh, di mana si pembicara berusaha meyakinkan pihak lain bahwa apa yang disampaikan adalah benar dan rasional, dengan tidak bermaksud merendahkan pendapat atau pandangan orang yang diajak bicara tersebut. Dengan demikian, qaul layyina adalah salah satu metode dakwah, karena tujuan utama dakwah adalah mengajak orang lain kepada kebenaran, bukan untuk memaksa dan unjuk kekuatan.

Ada hal yang menarik untuk dikritisi, misalnya, kenapa Musa harus berkata lembut padahal Fir'aun adalah tokoh yang sangat jahat. Menurut al-Razi, ada dua alasan: pertama, sebab Musa pernah dididik dan ditanggung kehidupannya semasa bayi sampai dewasa. Hal ini, merupakan pendidikan bagi setiap orang, yakni bagaimana seharusnya bersikap kepada orang yang telah berjasa besar dalam hidupnya; kedua, biasanya seorang penguasa yang zalim itu cenderung bersikap lebih kasar dan kejam jika diperlakukan secara kasar dan dirasa tidak menghormatinya. 


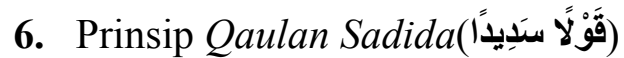

Di dalam al-Qur'an qaul sadida disebutkan dua kali, pertama, Q.s. an-Nisa'/4: 9 yaitu berbicara dengan benar:

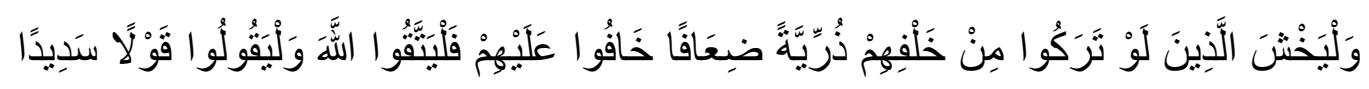

"Dan hendaklah takut (kepada Allah) orang-orang yang sekiranya mereka meninggalkan keturunan yang lemah di belakang mereka yang mereka khawatir atas (kesejahteraan)nya. Oleh sebab itu, hendaklah mereka bertaqwa kepada Allah, dan hendaklah mereka berbicara dengan tutur kata yang benar." (Q.s. al-Nisa'/4: 9)

Ayat ini turun dalam kasus seseorang yang mau meninggal bermaksud mewasiyatkan seluruh kekayaan kepada orang lain, padahal anak-anaknya masih membutuhkan harta tersebut. Dalam kasus ini, perkataan yang harus disampaikan kepadanya harus tepat dan argumentatif. Inilah makna qaul sadid. Misalnya, dengan perkatan, "bahwa anak-anakmu adalah yang paling berhak atas hartamu ini. Jika seluruhnya kamu wasiyatkan, bagaimana dengan nasib anak-anakmu kelak." Melalui ayat ini juga, Allah ingin mengingatkan kepada setiap orang tua hendaknya mempersiapkan masa depan anak-anaknya dengan sebaikbaiknya agar tidak hidup terlantar yang justru akan menjadi beban orang lain.

Ucapan yang benar adalah yang sesuai dengan Al-Quran, Assunnah, dan Ilmu. AlQuran menyindir keras orang-orang yang berdiskusi tanpa merujuk kepada Al-Kitab, petunjuk dan ilmu. Diantara manusia yang berdebat tentang Allah tanpa ilmu petunjuk dan kitab yang menerangi (Qs;31:20). Al-Quran menyatakan bahwa berbicara yang benar,menyampaikan pesan yang benar,adalah prasyarat untuk kebenaran (kebaikan, kemaslahatan) amal. Bila kita ingin menyukseskan karya kita, bila kita ingin memperbaiki masyarakat kita, maka kita harus menyebarkan pesan yang benar dengan perkataan yang lain. Hal ini berarti masyarakat menjadi rusak jika isi pesan komunikasi tidak benar. Dan kedua, Q.s. al-Ahzab/33: 70 yang artinya:

"Hai orang-orang yang beriman, bertakwalah kamu kepada Allah dan katakanlah perkataan yang benar. (Q.s. al-ahzab/33: 70)

Ayat ini diawali dengan seruan kepada orang-orang beriman. Hal ini menunjukkan bahwa salah satu konsekwensi keimanan adalah berkata dengan perkataan yang sadid. Atau dengan istilah lain, qaul sadid menduduki posisi yang cukup penting dalam konteks kualitas keimanan dan ketaqwaan seseorang. Sementara berkaitan dengan qaul sadid, terdapat banyak 
penafsiran, antara lain, perkataan yang jujur dan tepat sasaran. perkataan yang lembut dan mengandung pemuliaan bagi pihak lain, pembicaraan yang tepat sasaran dan logis, perkataan yang tidak menyakitkan pihak lain,perkataan yang memiliki kesesuaian antara yang diucapkan dengan apa yang ada di dalam hatinya.

\section{F. Konteks Komunikasi dalam Al-Quran}

Pembangunan komunikasi yang beradab bisa diklasifikasikan sebagai berikut:

1. Komunikasi dan Pendidikan(tarbiyah)

Sebuah pembangunan karakter (character building) tidak identik dengan transfer ilmu. Sehingga di dalam Islam diperkenalkan dengan istilah tarbiyah yang berasal dari rabbayurabbi-tarbiyatan yang didefinisikan oleh al-Ishfahani, yaitu mendorong dan mengawal pihak lain menuju kepada kesempurnaannya.

Dengan mengacu pengertian tersebut, maka pendidikan bukanlah bersifat indokrinasi atau propaganda, akan tetapi, suatu proses yang bersifat komunikatif. Dalam hal ini, bisa digunakan prinsip-prinsip qaul maisur, yaitu segala bentuk perkataan yang baik, lembut, dan melegakan; menjawab dengan cara yang sangat baik, benar dan tidak mengada-ada; mengucapkan dengan cara yang wajar. Semakin bertambah umur, maka metode yang digunakan tentu saja berbeda ketika masih anak-anak. Namun, secara prinsip tetap sama, yaitu melahirkan generasi yang berkaraker. Misalnya, pada saat sudah dewasa, maka yang diterapkan adalah prinsip-prinsip qaul sadida, yang di antaranya adalah tepat sasaran dan logis, memiliki kesesuaian antara apa yang ada di dalam hati dengan yang diucapkan.

Di sini proses komunikasi pendidikan tidak hanya dipahami sebagai proses transfer pengetahuan yang bersifat satu arah; akan tetapi, harus ada upaya yang sungguh-sungguh dari pihak pendidik/ guru, sebagai komunikator, untuk mampu memberikan keteladan yang baik, sebagai upaya bermeta-komunikasi. Juga kedua orang tuanya sebagai pendidik pertama dan utama bagi anak-anaknya. Bahkan, secara naluriah, seorang anak sangat senang dan bangga jika bisa meneladani kedua orang tuanya. Ketidak sempurnaan proses komunikasi pendidikan terjadi, misalnya hanya mengajarkan pelajaran-pelajaran yang berbasis kompetensi tetapi tidak menanamkan nilai-nilai berbasis karakter atau akhlaq. Bahkan, hal ini bisa dianggap sebagai bentuk kriminalitas pendidikan. Faktor kegagalan guru/orang tua dalam proses pendidikan, antara lain, disebabkan kegagalan membangun komunikasi yang beradab tersebut. 


\section{Komunikasi dan Dakwah}

Inti dakwah adalah mengajak orang lain untuk mengikuti apa yang diserukannya. Oleh karenanya,kemampuan berkomunikasi danbermetakomunikasi dengan baik adalah menduduki posisi yang cukup strategis. Demikian itu, karena Islam memandang bahwa setiap muslim adalah da'i. Sebagai da'i, ia senantiasa dituntut untuk mau dan mampu mengkomunikasikan ajaran-ajaran Ilahi secara baik. Sebab, kesalahan dalam mengkomunikasikan ajaran Islam, justru akan membawa akibat yang cukup serius dalam perkembangan dakwah Islam itu sendiri.

Dalam firman Allah dinyatakan:

"Hendaklah ada di antara kamu, suatu umat yang selalu mengajak kepada kebaikan, menyeru kepada yang ma'ruf dan mencegah dari yang munkar" (QS. Ali 'Imran/3: 104).

Ayat tersebut memberi arahan kepada setiap anggota masyarakat, terutama umat muslim, agar selalu mengajak kepada kebaikan (al-khair), memerintahkan dengan ma'ruf, dan mencegah dari yang munkar. Tentu saja, bukan tanpa sengaja jika ayat ini mendahulukan, da'wah ila al-khair dari pada al-amr bil-ma'ruf. Meskipun dari sisi penerjemahan keduanya bisa saja memiliki arti yang sama, yaitu 'kebaikan', namun oleh para ahli tafsir, kata al-khair dipahami sebagai kebaikan yang bersifat universal, seperti keadilan, kejujuran, kepedulian sosial, dan lain-lain. Artinya, konsep ini juga harus dipandang sebagai konsep universal. Dengan demikian, mengajak kepada al-khair, sebenarnya juga menjadi concern bagi agama-agama di luar Islam. Sebab, setiap agama selalu menghendaki terciptanya kehidupan yang harmonis, aman, tentram, saling menghormati sesama, dan sebagainya. Oleh karena itu, sebagai bagian dari masyarakat, mereka harus memiliki komitmen yang sama untuk peduli terhadap segala bentuk prilaku-prilaku anti sosial yang terjadi di masyarakatnya. Dalam hal ini, umat muslim harus senantiasa tampil yang terdepan untuk menyeru atau mengkomunikasikan, sekaligus memberi keteladanan.

Dengan demikian, tegaknya nilai-nilai hubungan sosial yang luhur adalah sebagai kelanjutan dari tegaknya nilai-nilai keadaban itu. Artinya, masing-masing pribadi atau kelompok, dalam suatu lingkungan sosial yang lebih luas, memiliki kesediaan memandang yang lain dengan penghargaan, betapapun perbedaan yang ada, tanpa saling memaksakan kehendak, pendapat, atau pandangan sendiri. 


\section{G. Kesimpulan}

Islam mengajarkan umatnya agar mampu berkomunikasi dengan baik. Karna manusia sebagai makhluk sosial menduduki posisi yang sangat penting dan strategis. Sebab, hanya manusialah satu-satunya makhluk yang diberi karunia bisa berbicara. Dengan kemampuan bicara itulah, memungkinkan manusia membangun hubungan sosialnya. Kemampuan bicara berarti kemampuan berkomunikasi. Berkomunikasi adalah sesuatu yang dihajatkan di hampir setiap kegiatan manusia. Dalam sebuah penelitian telah dibuktikan, hampir $75 \%$ sejak bangun dari tidur manusia berada dalam kegiatan komunikasi. Dengan komunikasi kita dapat membentuk saling pengertian dan menumbuhkan persahabatan, memelihara kasih sayang, menyebarkan pengetahuan, dan melestarikan peradaban. Tetapi, dengan komunikasi kita juga dapat menumbuhsuburkan perpecahan, menghidupkan permusuhan, menanamkan kebencian, merintangi kemajuan, dan menghambat pemikiran. 


\section{DAFTAR PUSTAKA}

Amir, Mafri, Etika Komunikasi Massa dalam Pandangan Islam. Penerbit: Logos Wacana Ilmu. Jakarta. 1999.

Al-Ashfahani, Abu al-Qasim Abu al-Husain bin Muhammad al-Raghib, al-Mufradat fi alGharib al-Qur 'an, Mesir: Mushthofa al-Bab al-halabi, 1961.

Al-Maraghi, Mushthofa, Tafsir al-Maraghi, Beirut: Dar al-Fikr,1964.

Al-Qurthubi, Al-Jāmi' li ahkām Al-Qur'ān, Bairut : Dar al-Fikri.thn 1994

Guyadi, YS. Himpunan Istilah Komunikasi, Jakarta: Grasindo, 1998.

Rahmat, Jalaluddin. Islam Aktual, Bandung: Mizan, 1992.

Shihab, Muhammad Quraish. Wawasan al-Qur `an. cet. II, Bandung: Mizan, 1996 